\title{
百日咳菌の研究
}

\section{第五編 百日晤の経過と菌型との関係}

\author{
春日忠善 中瀨 安清 浮㿟 光威 高津 邦芳 \\ 北黑研究所 (部長 春日忠善)
}

[受付：2月 27 日 1954 年]

百日暖菌の菌型問題は比較的分離後継代数の少ない菌 林と人工培领を重ねた保存㧣との閪又は保存株相互の間 に付いて研究されて来た。私共は第一編1)及び二良》で 集落所見上区別し難いsmooth 集落の百日晐菌が抗原棈 造上 I 型, III 型及び移行型に分類されることを述べた。 この様な抗原棈造を異にする菌が患者の病果にも存する ものであろらか?，又もし存するとすれば百日喛の感染 や経過之如何なる関係があるであろうか? 等を主眼とし たのがこの研究である。

\section{I. 研究の方法}

種々の発病日の百日咳様患児の鼻咽腔後壁及び咽頭粘 膜面より得た材料を直ちに Bordet-Gengou 平板に塗

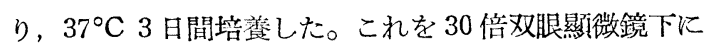
て観察しつ〉集落所見とスライド子满凝集にて疑わしい 集落を可及的 10 個宛鈎菌した。この際第一絴に述べた 各型の集洛の特徵に留意し，もし混在するならばこれ等 総ての型の菌が鉤菌される様につとめた。これを B-G

斜面に 1 代純培隻し，LS支びO因子血清との凝集反忍 によつて菌型を決定した。

\section{II. 患者より菌株の分離}

1952 年 5 月より 10 月迄の期間に, 塖信病院及び赤十 与病院小巟科に於ける百日喛桹患者 216 名に付いて, 経 過日を異にして可及的頻回分離を試み，延 860 例に達し た。この中菌の分離された者は 216 名中 91 名 (42\%)， 延 860 例中 187 例 $(21 \%)$ であつた。

\section{III. 病歷日と菌型との関係}

同一患者から同時に分離された各集落の菌型を見るに

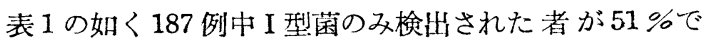
他はI型と移行型の混合 $19 \%$, 移行型のみ $30 \%$, 移行 型と III 型の混合 ( $3 \%)$ であつた。

これを発病よりの経過日数別に見るとI型のみ検出さ れた者と移行型及び III 型の検出された者との割合は 5 日以内では $9: 4$ でめつたが $6 〜 10$ 日では $39: 22$ となり
第 1 表 菌を分類した病歷日と菌型

\begin{tabular}{|c|c|c|c|c|c|c|c|}
\hline 病䊬日 & $\begin{array}{l}\text { 例 } \\
\text { 数 }\end{array}$ & $\begin{array}{c}\text { I } \\
\text { 型 }\end{array}$ & $\begin{array}{l}\text { I 移 } \\
\text { 型行 } \\
\text { と型 }\end{array}$ & $\begin{array}{l}\text { 䔟 } \\
\text { 行 } \\
\text { 型 }\end{array}$ & $\begin{array}{l}\text { 移 } \\
\text { 行III } \\
\text { 型型 }\end{array}$ & $\begin{array}{l}\text { 不 } \\
\text { 詳 }\end{array}$ & $\begin{array}{c}\text { I } \\
\text { 犁 }\end{array}$ \\
\hline $1 \sim 5$ & 13 & 9 & 1 & 3 & & & $9: 4$ \\
\hline $6 \sim 10$ & 61 & 39 & 9 & 11 & & 2 & $39: 22$ \\
\hline $11 \sim 20$ & 73 & 34 & 5 & 30 & 4 & & $34: 39$ \\
\hline $21 \sim 30$ & 17 & 5 & 6 & 5 & 1 & & $5: 12$ \\
\hline $31 \sim$ & 19 & 7 & 4 & 7 & 1 & & $7: 12$ \\
\hline 不 詳 & 4 & 3 & 1 & & & & $3:-1$ \\
\hline 計 & 187 & 97 & 26 & 56 & 6 & 2 & $97: 88$ \\
\hline$\%$ & 100 & 51 & 19 & 30 & 3 & 1 & $52: 48$ \\
\hline
\end{tabular}

11〜20日の者では $34: 39,21$ 日以後の者では 12:24で あつた。即ち発病の初期にはI型のみ検出される者が多 く，経過の進むに往つて移行型及び III 型の検出される 者が多かつた。

\section{IV 同一患者から病歴日を異にし分離された菌の菌型}

同一患者から病磨日を異にして分離した成績（図 1 ) を見るに全経過を通じI型の分分離された者が 39 例中 12 例 (31\%), 始めI 型のみで後に移行型を混じ又は移 行型のみとなり或いは移行型と III 型を混じたものが17 例 (44\%), 終始I 型に移行型を混じ又は移行型のみ検 出された者 10 例 $(26 \%)$ であつた。即ちこの試験でる 初めI型のみであつた患者が経過の進むに従つて移行型 及び III 型に变化する者の多いことを示した。

終始移行型を混じ又は移行型のみであつた 10 例が移 行型による感染であつたか否かはこれ丈けでは不明であ

KASUGA Tadayoshi, NAKASE Yasukiyo UKISHIMA Koi and TAKATSU Kuniyoshi : Studies on Haemophillus pertussis. Part 5 The types of $\mathbf{H}$. pertussis isolated from various progress of Whooping-cough. Kitasato Institute. - Jap. J. of Bact. $9(5), 345-347,1954$. 
龱 1 阔一患者に於ける病歴日と分離されを菌型

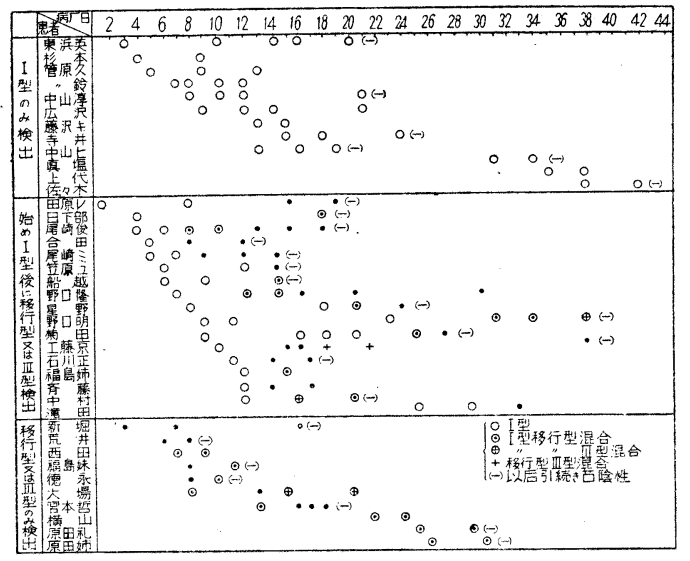

ろう。

\section{V. 移行型による感染}

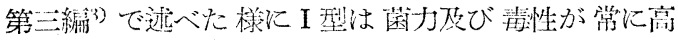
く，移行型は変暴の积度によつて I 型に近い菌力及び毒 性のものから III 型に近いもの迄女り，III 型は植めて 弱。

自然の流行に於て移行型が極めて高涪に排渄されるこ とは II, III に述べた如くで岁るが，この際移行型によ る感染は起らないであろうか。

このためには感染経路の略明かな家族内二次惄染に於 て, 先に発症した者の排浛する菌型が移行型に变化して から潜伏期风そ 1 週間以上を経て発豦した例の菌型を調 ベることがーつの方法であうう。この研案中家族内二达 感染を起した例が 10 例要つたが，いずれも一次感染(先 に発病した）者がI型囷を排菌している時期の 1 週以内 に発症した例のみであつて，二次感染者より発病後始め て分離した囷はいずれもI型菌であつた。良つて移行贸!

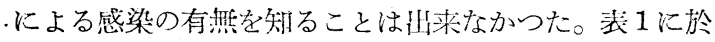
て発病 10 日上队に移行型のみ检Hされた 14 例の分離病 歷日は，発病 3 日目 1 例，4日日2例，6日目 2 例， 7 日日1例，8日目6例，10日月2例であつた。龱1でI 型の感染を受け体内で移行型变異を起したと考之られる 例は最も早いもので発病 8 日目であつた。このことから すると発病 3〜4 日目に移行型の及分離された例の如き は移行型による感染ではあるほいか。

\section{Bordet Gengue 培地継代による変異性の相違}

発病後の経過日を暴にして分離した I 型菌は B-G 培 地継代によつて I 型 $\rightarrow$ 移行型 $\rightarrow$ III 型に変異するのに相 異あるかを検した。即ち备 I 型菌を B-G 斜面に $37^{\circ} \mathrm{C}$ に3日置きに 30 代継代し，各代に於ける斜面菌をL S

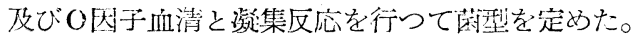

a）分離病歷日と变珙の難㫗

発病 1 〜日目迄に分離した I 型菌 10 株中 7 株 $(70$ \%)はB-G 継代 30 代に等るもI型を保持したが，6〜

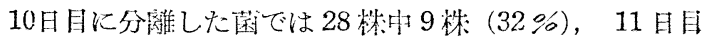
以降に分離した菌では 40 株中㮖かに 7 株 (18\%) がI 型を保持したに逼ざなからた。（关2）

\section{第 2 表 分離した病歷日と B-G 培地 30 代継代によるI 型菌の変異}

\begin{tabular}{|c|c|c|c|c|c|}
\hline \multirow{2}{*}{ 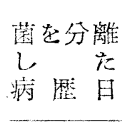 } & $\begin{array}{c}\text { I 型老 } \\
\text { 保 持 }\end{array}$ & \multicolumn{2}{|c|}{ 移行型に変舅 } & \multicolumn{2}{|c|}{ III型に変異 } \\
\hline & 株 数 & 株 数 & 变異した & 株 数 & 变琵した \\
\hline $1 \sim 5$ & 7 & 3 & 13代 & & \\
\hline $6 \sim 10$ & 9 & 19 & 9代 & 4 & 13代: \\
\hline $11 \sim 15$ & 4 & 19 & 8代 & 1 & 11代 \\
\hline $16 \sim 20$ & 2 & 7 & 8代 & 2 & 27 代 \\
\hline $21 \sim 30$ & 1 & 7 & 7代 & & \\
\hline 計 & 23 & 55 & & 7 & \\
\hline
\end{tabular}

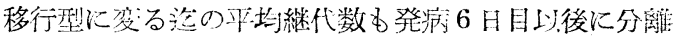
した菌のすが，冬れ以前に分離した菌上りも短かかつ

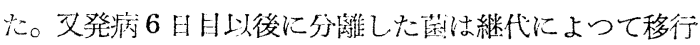
型より更に淮んで III 型に資化したものが7株岕つた。

即占発病 5 日以内に分離されたI 型菌は, それ以後に 分離された I 型菌より B-G培地継代に対し安定な㥞であ る。

b）同一患者より病歷日を晎にして分離した菌の变珙 性

同一患者より病厢日を暴にして分離した I 型菌相年。の B-G 継代による変晎性を比較するに, 就れの例に於ても 早い病歷日に分離した菌よりも遅い病歷日に分離した菌 の方が継代数の少ない中に移行型に变化した。

即らこの際も(a) と同じことが云える。更に患児の全 経過を通じてI型菌のみ検出された例では，5例中 3 例 に於て 13〜20病歷日と云了比較的遅い病歷日に分離さ れた I 型葫が B-G 30 代継代によつても省I型学保持し た。

即ち全経過を通じ I 型菌のみ检出される如き患児の菌 快，分離病歷日の早い䐅いに係らず，B-G 継代に対して も安定な样である。

\section{VII 考按}

1）新しく分離した I 型菌をB.Gに継代した際に斜面 の菌が移行型の反応を示すに至る平均代数は（表 2) 8 〜6代であつた。このことから序当に製造された B-G培 
地に分離し， 1 代純培荃した 2 代菌又は 3 代菌は病楽の 菌の菌型を示すと見做されるであるう。

私共の成績では 約 $51 \%$ \% 型のみであるに過ぎずし て, そ他は I 型と移行型の混合, 移行型の久久は移行 型と III 型の混合であつた。この㥞に病梀の菌が単一型 でないことは新しい知見であつて, 種々の面に烡大な関 係を持つるのであろう。

2）私共は第 4 報4) で I 型菌ワクチンはマウス脳内感 染に対し强い色疼性を有するが，III 型菌ワクチンには ここ礼を䡃め得ず，移行型ワクチンは雨者の間の種々の程 度の力何を示すことを報告した。莎鮮分離菌がこの実験 成樍の如く約 $50 \%$ 它が移行型（時には III 型）である ことは, 新蟹分離䔉でつつたワクチンのカ洒汇差の女 ると云うこれ迄の諸家の成績（第一編文献参照）の一因 であると思われる。

3）発病の初期注 I 型菌が多く, 経過の進むに往つ て移行型の多くなる（表1）こと，同一患者で始めI型 であつた者が経過の淮む往つて移行型, 時にはIII 型 に变化する (図 1 ) ことは, 体内に於てI型 $\rightarrow$ 移行型 $\rightarrow$

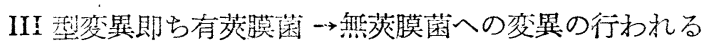
ことを示している。この現象はチフス回復期に $\mathrm{V} \rightarrow \mathrm{W}$ 変 異の見られること, ペストの無毒生菌ワクチン注射によ つて強い免疫状態汇るもルモットに Envelope を有す る強毒菌を注射すると, その菌は Envelopeを失つた変 異を体内で起すことなど同じ機序によるものと解され る。又発病の初期に分離した I 型菌よりも迤礼て分離し
た菌の方が B-G培地継代によつて速かに I 型 移行型変 暴を起すのは, 遅れて分離した菌の方がより多く感染免 疫の影響を受けているためではなかららか。

4）Ｉ型菌による感染の多いことは, 発病早期に I 型 菌の多い (5 日以内 $70 \%)$ ことで知れる。然し発病 10 日以後に於て移行型の菌を排泄する患者が半数以上も存 することは移行型による感染の可能性を考兄させる。

図1でI型の感染を受け，休内で移行型変異を起した と解される例は最も早いもので発病 8 日目であつた。従 つて表 1 で発病 $3 ， 4$ 日目に既汇移行型の菌のみ検出さ れた例の如きは移行型による感染ではなからうか。

\section{VIII 結 緦}

患児の病亲からもI型菌の外, 極めて高率に移行型及 びIII 型菌が分離された。

発病は初期には I 型菌が多く, 経過の進むに従つて移 行型菌の検出率が多くなつた。

病巣にある移行型菌及び III 型菌は I 型菌が体内で変 異したものと移行型菌による感染と思われるものとがあ つた。

患者より材料の探取及び培盖を担任して下さつた聥信 病院浜田医長, 篠田, 藤野両学士及び゙赤十字病院内藤医 長, 丸山学士に深謝する。

\section{交献}

1）春日忠善, 外三名 : 日本細菌誌，8，841，1953.

2) 春日忠善, 外三名: 日本細菌誌, $8,927,1953$.

3）春日忠善, 外三名: 日本細菌誌，9，53，1954,

4）春日忠善, 外三名：日本細菌誌，9，99，1954, 